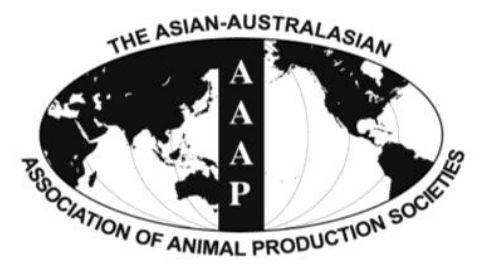

Asian-Aust. J. Anim. Sci.

Vol. 25, No. 11 : 1568-1574 November 2012

http://dx.doi.org/10.5713/ajas.2012.12379

www.ajas.info

pISSN 1011-2367 eISSN 1976-5517

\title{
Effects of Synchronization of Carbohydrate and Protein Supply in Total Mixed Ration with Korean Rice Wine Residue on Ruminal Fermentation, Nitrogen Metabolism and Microbial Protein Synthesis in Holstein Steers
}

\author{
Min Yu Piao, Hyun J. Kim, J. K. Seo, T. S. Park, J. S. Yoon, K. H. Kim ${ }^{1}$ and Jong K. Ha* \\ Department of Agriculture Biotechnology and Research Institute for Agriculture and Life Sciences, \\ College of Agriculture and Life Science, Seoul National University, Seoul 151-742, Korea
}

\begin{abstract}
Three Holstein steers in the growing phase, each with a ruminal cannula, were used to test the hypothesis that the synchronization of the hourly rate of carbohydrate and nitrogen $(\mathrm{N})$ released in the rumen would increase the amount of retained nitrogen for growth and thus improve the efficiency of microbial protein synthesis (EMPS). In Experiment 1, in situ degradability coefficients of carbohydrate and $\mathrm{N}$ in feeds including Korean rice wine residue (RWR) were determined. In Experiment 2, three total mixed ration (TMR) diets having different rates of carbohydrate and $\mathrm{N}$ release in the rumen were formulated using the in situ degradability of the feeds. All diets were made to contain similar contents of crude protein (CP) and neutral detergent fiber (NDF) but varied in their hourly pattern of nutrient release. The synchrony index of the three TMRs was 0.51 (LS), 0.77 (MS) and 0.95 (HS), respectively. The diets were fed at a restricted level ( $2 \%$ of the animal's body weight) in a $3 \times 3$ Latin-square design. Synchronizing the hourly supply of energy and $\mathrm{N}$ in the rumen did not significantly alter the digestibility of dry matter, organic matter, crude protein, NDF or acid detergent fiber (ADF) ( $>>0.05)$. The ruminal $\mathrm{NH}_{3}-\mathrm{N}$ content of the LS group at three hours after feeding was significantly higher $(\mathrm{p}<0.05)$ than that of the other groups; however, the mean values of ruminal $\mathrm{NH}_{3}-\mathrm{N}, \mathrm{pH}$ and VFA concentration among the three groups were not significantly different ( $\mathrm{p}>0.05)$. In addition, the purine derivative (PD) excretion in urine and microbial-N production (MN) among the three groups were not significantly different ( $p>0.05$ ). In conclusion, synchronizing dietary energy and $\mathrm{N}$ supply to the rumen did not have a major effect on nutrient digestion or microbial protein synthesis (MPS) in Holstein steers. (Key Words: By-product, Dairy Steer, Microbial Protein Synthesis, Purine Derivative, Rice Wine Residue, Synchronization)
\end{abstract}

\section{INTRODUCTION}

Along with an increase in the human population and various natural disasters year by year, the supply of animal feed is gradually being reduced, followed by elevation of the cost of internationally traded feed. Therefore, alternative feedstuffs have been explored rather extensively throughout the world. One group of alternative feedstuffs is that composed of secondary products obtained during processing of a primary commodity. The use of food byproducts as animal feed satisfies not only a nutritional requirement for animals, but also provides a suitable

\footnotetext{
* Corresponding Author: Jong K. Ha. Tel: +82-2-880-4809, Fax: +82-2-875-8710, E-mail: jongha@snu.ac.kr

${ }^{1}$ Department of Nutrition and Physiology, National institute of animal science, RDA, Suwon 441-706, Republic of Korea. Submitted Jul. 7, 2012; Accepted Sept. 11, 2012; Revised Sept. 17, 2012
}

disposal method for this by-product, thereby reducing environmental pollution and economic loss. Generally, many by-products are rich in crude protein $(\mathrm{CP})$, watersoluble carbohydrate (WSC), and cellulose; thus, it was suggested that food by-products may have high potential as animal feed (Chiou et al., 1998; Xu et al., 2006).

In Korea, traditional rice wine is very popular, with increasing consumption in recent years. Therefore, annual production of rice wine residue is increasing. It is notable that the production method and materials used in rice wine making are very similar to that of beer. Rice wine is also rich in yeast that is useful for human health; thus, there is a good chance that rice wine residue also contains some yeast.

An excessive supply or an inefficient use of feed nutrients brings about large amounts of waste released to the environment, and the most serious pollutants from these wastes are nitrogen, phosphorus and other organic 
compounds (e.g., methane and nitrous oxide) (Yang et al., 2010). Also, preduodenal losses of $\mathrm{N}$ can account for up to $30 \%$ of ingested $\mathrm{N}$, although microbial protein is synthesized efficiently in the rumen of cattle fed diets consisting of high quality pasture plants (Beever et al., 1986). This loss of $\mathrm{N}$ occurs in the form of urine when concentration of ruminal ammonia is high due to the extensive and rapid ruminal degradation of pasture $\mathrm{N}$ (Beever et al., 1986; Van Vuuren et al., 1991). It is generally reported that microbial protein synthesis in the rumen is the most important occurrence in maximizing the amino acid supply to a ruminant, and it leads to reduction of loss of ruminal ammonia. Microbial protein is known to be of high quality with good amino acid composition for ruminants (Clark et al., 1992), and it may account for the majority (40 to $80 \%$ ) of amino acids absorbed in the small intestine under certain conditions, depending on several dietary and animal factors (Owens and Bergen, 1983). Generally, matching or synchronizing the hourly supply of energy and $\mathrm{N}$ in the rumen has been suggested to improve the efficiency of microbial protein synthesis (Hoover and Stokes, 1991). It is theoretically possible that a synchronous supply of $\mathrm{N}$ and energy to the rumen would improve the efficiency of microbes in utilizing ATP and capturing $\mathrm{N}$ for microbial growth (Johnson, 1976; Herrera-Saldana et al., 1990; Sinclair et al., 1991; 1993; Richardson et al., 2003). However, other researchers have claimed no significant effect on microbial population. In addition, the energy source in the diet has been shown to be more influential than synchrony (Henning et al., 1993; Shabi et al., 1998). Since Sinclair (1991) suggested the hypothesis that when calculating the synchrony index for nitrogen to carbohydrate supply a figure of $32 \mathrm{~g} \mathrm{~N} / \mathrm{kg}$ carbohydrate degraded in the rumen, a synchrony index of 1 represents perfect synchrony between $\mathrm{N}$ and energy supply throughout the day, while values $<1$ indicate the degree of asynchrony. The objective of this study was to evaluate the effect of a total mixed ration (TMR) with rice wine residue (RWR) as one of the main ingredients at different synchrony indexes (SIs) on nutrient digestibility, $\mathrm{N}$ retention and microbial protein synthesis in the rumen.

\section{MATERIAL AND METHODS}

\section{Experiment 1: Determination of in situ degradability of ingredients for SI calculation}

Experimental materials and incubation procedures: Holstein steers (approximately $750 \mathrm{~kg}$ ) with ruminal cannulas were used to determine the in situ ruminal degradation rate of test feeds. The steers were offered $6 \mathrm{~kg}$ timothy grass and $4 \mathrm{~kg}$ concentrate (Table 1) per day, and mineral blocks and water were available ad libitum. Five
Table 1. Chemical characteristics of concentrate and timothy fed to steers

\begin{tabular}{lcc}
\hline Item & Concentrate & Timothy \\
\hline Dry matter & 87.62 & 89.35 \\
Crude protein & 12.5 & 6.16 \\
Crude fat & 3 & 2.07 \\
Crude fiber & 20 & 36.21 \\
Crude ash & 10 & 4.76 \\
$\mathrm{Ca}$ & 0.8 & 0.18 \\
$\mathrm{P}$ & 0.8 & 0.2 \\
\hline
\end{tabular}

test feeds (rice wine residue, soybean meal, wheat bran, corn and timothy) were used for the in situ disappearance test, and the measurements were performed in triplicate. Samples of all test feeds except RWR were milled through a $1 \mathrm{~mm}$ screen using a laboratory mill. A total of 126 nylon bags $(110 \times 220 \mathrm{~mm}, 53 \mu \mathrm{m}$ pore size $)$ containing $20 \mathrm{~g}$ of test feeds were heat sealed and distributed into seven mesh bags (18 nylon bags per mesh bag) for each incubation time. Nylon bags were removed from the rumen after 0, 3, 6, 9, 12, 24 and $48 \mathrm{~h}$ incubation. The bags were then washed under cold running tap water until there was no color visible in the rinse water. Finally, the nylon bags were dried at $65^{\circ} \mathrm{C}$ for $48 \mathrm{~h}$ and weighed to determine the dry matter disappearance rate. The contents remaining in the nylon bags were stored at $-20^{\circ} \mathrm{C}$ until chemical analysis.

Chemical analysis and calculation of the degradability coefficients and synchrony index: Crude protein (CP, $\mathrm{N} \times 6.25$ ) and ether extract (EE) were determined by the AOAC (1990) method. Crude ash was determined by heating samples at $600^{\circ} \mathrm{C}$ for $3 \mathrm{~h}$. Ruminal disappearance rate of test feed at each individual incubation time was calculated as the difference between the contents in the initial samples and the residues remaining after incubation in the rumen and expressed as a percentage of the content of the initial sample. Kinetic parameters of nutrient disappearance in the rumen were estimated using the following model (Orskov and McDonald, 1979):

$$
P=a+b\left(1-e^{-c t}\right)
$$

Where $\mathrm{P}$ was the cumulative amount degraded in the rumen at time $\mathrm{t}(\%)$, a was the readily soluble fraction $(\%)$, $\mathrm{b}$ was the fraction potentially degraded in the rumen $(\%)$, c was the constant rate of degradation of $b(\% / h)$, and $t$ was the time of incubation (h). The potentially degradable fraction was calculated as $(a+b)$. The effective ruminal degradability (ERD) was calculated from the following equation:

$$
\mathrm{ERD}=\mathrm{a}+((\mathrm{b} \times \mathrm{c}) /(\mathrm{c}+\mathrm{k}))
$$


Where constants a, b and c were defined previously, and $\mathrm{k}$ was the fractional flow rate from the rumen (\%). In addition, from the hourly quantity of $\mathrm{CHO}$ and $\mathrm{N}$ degraded, a synchrony index of nitrogen to carbohydrate was then calculated as per Sinclair et al. (1991).

Experiment 2: Effects of dietary SI on nutrient digestion, $\mathrm{N}$ retention and microbial protein

Preparation of experimental diets: Three different TMRs having similar crude protein contents with different synchrony indexes (SI) were formulated with the same test feeds used in Experiment 1 together with urea, as shown in Table 4. The synchrony index of the three experimental diets was adjusted to 0.51 (LS), 0.77 (MS) and 0.95 (HS), respectively, with varying mixing ratios of test feed and urea. The degradation rate of carbohydrate and $\mathrm{N}$ fraction of each test feed was calculated by the method described at Experiment 1. The diets were formulated according to the NRC (2000) requirements for beef cattle.

Experimental materials and procedures: Three Holstein steers $(360 \pm 20 \mathrm{~kg})$ fitted with a ruminal cannula were fed three different diets in order to evaluate the effects of synchronization of released $\mathrm{N}$ and $\mathrm{CHO}$ in the rumen on rumen fermentation, $\mathrm{N}$ metabolism and microbial protein synthesis (MPS). The experimental design was a $3 \times 3$ Latin square with seven days for adaptation and five days for sampling in each period. The steers were fed respective experimental diets at $2 \%$ of their body weight in two equal portions at 08:00 and 20:00 (Table 4).

Sampling and chemical analysis: Urine samples were collected for four successive days using a stainless receptacle which contained $500 \mathrm{ml} 4 \mathrm{~N} \mathrm{H}_{2} \mathrm{SO}_{4}$ to prevent $\mathrm{N}$ loss. The urine was sub-sampled at an output rate of $3 \%$ and was frozen at $-20^{\circ} \mathrm{C}$ until analysis.

Total nitrogen concentration was analyzed using the Kjeldahl method (AOAC, 1990). In order to estimate the amount of microbial-N absorbed, urine was analyzed for purine derivatives (uric acid and allantoin) according to the modified method (George et al., 2006) of Chen et al. (1990). From the value of purine derivatives calculated, the amount of microbial-N absorbed was estimated indirectly using the method of Chen et al. (1992).

Total feces were collected at 8:00 before the morning feeding during each sampling period, and a $3 \%$ aliquot of total feces was collected, dried in a $65^{\circ} \mathrm{C}$ dry oven for $72 \mathrm{~h}$ and then ground with a mixer to pass through a $2 \mathrm{~mm}$ screen. Feces and feed samples were used for the analysis of DM, OM and N content according to AOAC (1990), and ADF and NDF were determined according to the method of Van Soest et al. (1991). Ruminal fluid was collected through the cannula on the last day of each period at $0,3,6$, 9 and $12 \mathrm{~h}$ after the morning feeding. Ruminal $\mathrm{pH}$ was measured by a $\mathrm{pH}$ meter (Mettler, Delta 340), ruminal fluid was centrifuged at $3,000 \mathrm{rpm}$ for $15 \mathrm{~min}$, and the supernatant was harvested to measure the $\mathrm{NH}_{3}-\mathrm{N}$ and VFAs concentrations. $\mathrm{NH}_{3}-\mathrm{N}$ concentration was determined using a modified colorimetric method (Chaney and Marbach, 1962), and concentrations of volatile fatty acid were determined by gas chromatography using a Agilent Tech 7890A (Hewlett Packard Strasse 876337 Waldbronn, Germany) for which a Supelco $(30 \mathrm{~m} \times 0.25 \mathrm{~mm} \times 0.25 \mu \mathrm{m}$, fused silica capillary column) column was used.

\section{Statistical analysis}

Obtained data were analyzed using the ANOVA procedure of Statistical Analysis System (SAS, 2002), and the differences among means were compared by Tukey's Test (Snedecor and Cocharn, 1967).

\section{RESULTS}

Chemical compositions of the five feed ingredients tested in Experiment 1 are presented in Table 2, and their degradability coefficients are shown in Table 3. Regarding protein degradability of the five feed ingredients tested, corn had the lowest " $a$ " fraction and highest " $b$ " fraction with the lowest rate of degradation $(c)$ of the potentially degradable protein fraction $(b)$, resulting in low effective degradability (ED). Wheat bran had higher " $a$ " and " $b$ " fractions with a rapid degradation of " $b$ " fraction compared to the other ingredients. The protein degradation of RWR was close to that of corn. The carbohydrate fraction of corn was highly degradable with the highest effective degradability. RWR was similar to corn in carbohydrate degradability characteristics. The apparent total tract digestibility values of dry matter, organic matter, ADF, NDF and $\mathrm{N}$ retention are presented in Table 5 (Experiment 2). Experimental diets formulated to have different SIs with similar composition did not influence DM, OM, ADF or NDF digestibility, or $\mathrm{N}$ retention $(\mathrm{p}>0.05)$. The ruminal fermentation characteristics of steers fed the three kinds of TMRs are presented in Table 6. The diurnal variations in

Table 2. Chemical composition of ingredients tested for ruminal degradability (\% DM basis)

\begin{tabular}{lrrrrr}
\hline Item & $\begin{array}{c}\text { Wheat } \\
\text { bran }\end{array}$ & Corn & SBM & RWR & Timothy \\
\hline DM & 90.35 & 87.47 & 88.25 & \multicolumn{1}{c}{36} & 90.88 \\
CP & 17.78 & 8.00 & 52.60 & 28.67 & 6.70 \\
EE & 4.80 & 4.28 & 2.32 & 3.07 & 2.41 \\
Ash & 5.14 & 1.27 & 6.72 & 0.66 & 7.30 \\
Crude fiber & 11.21 & 1.79 & 6.55 & 2.61 & 39.30 \\
ADF & 13.25 & 2.54 & 8.23 & 9.58 & 42.14 \\
NDF & 42.52 & 11.63 & 16.41 & 17.78 & 70.99 \\
Ca & 0.11 & 0.02 & 0.36 & 0.04 & 0.17 \\
P & 0.99 & 0.27 & 0.74 & 0.14 & 0.22 \\
NFE & 61.07 & 84.66 & 31.81 & 64.99 & 44.29 \\
\hline
\end{tabular}


Table 3. Ruminal degradability of $\mathrm{N}$ and carbohydrates in the ingredients used for experimental diets

\begin{tabular}{|c|c|c|c|c|c|c|}
\hline \multicolumn{2}{|c|}{ In situ degradability coefficients } & \multirow[t]{2}{*}{ Wheat bran } & \multirow[t]{2}{*}{ SBM } & \multirow[t]{2}{*}{ Corn } & \multirow[t]{2}{*}{ RWR } & \multirow[t]{2}{*}{ Timothy } \\
\hline $\mathrm{N}$ & & & & & & \\
\hline & a & 22.12 & 0.14 & 0.00 & 11.72 & 4.35 \\
\hline & $\mathrm{b}$ & 60.32 & 99.86 & 100.00 & 88.28 & 36.82 \\
\hline & $\mathrm{c}(/ \mathrm{h})$ & 0.10 & 0.03 & 0.02 & 0.02 & 0.04 \\
\hline \multicolumn{7}{|l|}{ ED } \\
\hline \multirow[t]{3}{*}{$\mathrm{k}(/ \mathrm{h})$} & 0.02 & 72.50 & 56.20 & 44.75 & 59.69 & 28.38 \\
\hline & 0.05 & 62.51 & 33.95 & 24.47 & 40.19 & 20.15 \\
\hline & 0.08 & 55.83 & 24.35 & 16.84 & 31.96 & 16.12 \\
\hline \multicolumn{7}{|l|}{$\mathrm{CHO}$} \\
\hline & a & 8.79 & 39.13 & 0.22 & 28.44 & 15.68 \\
\hline & $\mathrm{b}$ & 52.26 & 53.29 & 99.78 & 71.56 & 31.80 \\
\hline & $\mathrm{c}(/ \mathrm{h})$ & 0.11 & 0.09 & 0.03 & 0.06 & 0.05 \\
\hline \multicolumn{7}{|l|}{$\mathrm{ED}$} \\
\hline \multirow[t]{3}{*}{$\mathrm{k}(/ \mathrm{h})$} & 0.02 & 53.06 & 82.72 & 61.77 & 81.34 & 38.75 \\
\hline & 0.05 & 44.80 & 73.37 & 39.31 & 66.47 & 32.02 \\
\hline & 0.08 & 39.14 & 67.33 & 28.86 & 58.12 & 28.33 \\
\hline
\end{tabular}

Table 4. Ingredients and chemical composition of experimental diets (\% of DM)

\begin{tabular}{lccc}
\hline & Control & $\mathrm{T}-1$ & $\mathrm{~T}-2$ \\
\cline { 2 - 4 } Composition & \multicolumn{3}{c}{ Synchrony index } \\
\cline { 2 - 4 } & 0.51 & 0.77 & 0.95 \\
\hline Ingredient & 5 & 5 & 5 \\
Wheat bran & 48.6 & 41.3 & 34 \\
Corn & 5 & 5 & 5 \\
SBM & 0 & 8 & 16 \\
RWR & 40 & 40 & 40 \\
Timothy & 1.4 & 0.7 & 0 \\
Urea & & & \\
Nutrient & 16.15 & 16.76 & 17.87 \\
CP & 4.26 & 5.24 & 6.38 \\
Fat & 16.47 & 17.43 & 20.44 \\
ADF & 31.78 & 32.54 & 36.52 \\
NDF & 1.63 & 1.38 & 1.14 \\
Ca & 0.42 & 0.43 & 0.43 \\
P & & &
\end{tabular}

ruminal $\mathrm{pH}$ of steers on different synchronous diets were not significantly different among the three groups. The ruminal $\mathrm{pH}$ values of steers fed the three diets decreased until $6 \mathrm{~h}$ after the morning feeding and then increased gradually until the 20:00 feeding. There was no significant effect of dietary SI on mean daily ruminal $\mathrm{NH}_{3}-\mathrm{N}$ concentrations except that the value of the control group (LS) at $3 \mathrm{~h}$ after the 08:00 feeding was significantly higher than those of the MS and HS treatments $(\mathrm{p}<0.05)$. The patterns of ruminal $\mathrm{NH}_{3}-\mathrm{N}$ concentration were similar among the three treatments, with peak concentrations of total VFA of the three treatments not significantly different. Even though the concentrations of individual VFAs of the LS group throughout daytime were numerically higher than those of MS and HS, there was no significant effect by synchronous treatment $(\mathrm{p}>0.05)$. The daily urinary output of purine derivatives (PD) and microbial-N synthesis of steers fed the three different synchronous diets are presented in Table 7. In terms of the daily contents of allantoin and uric acid in urine excreted by each steer, although higher SI TMR resulted in numerically more excretion than the control group, results were not significantly influenced by synchronous treatment $(\mathrm{p}>0.05)$. Microbial $\mathrm{N}$ calculated

Table 5. Apparent total tract digestibility (\%) and nitrogen balance in steers fed experimental diets

\begin{tabular}{|c|c|c|c|c|c|}
\hline \multirow{2}{*}{ Item } & \multicolumn{3}{|c|}{ Treatments } & \multirow{2}{*}{ SEM } & \multirow{2}{*}{$\mathrm{p}$ value } \\
\hline & Control & $\mathrm{T}-1$ & $\mathrm{~T}-2$ & & \\
\hline \multicolumn{6}{|l|}{$\overline{\text { Digestibility (\%) }}$} \\
\hline Dry matter & 69.10 & 69.67 & 69.61 & 0.44 & 0.8738 \\
\hline Organic matter & 71.28 & 71.69 & 71.58 & 0.51 & 0.9581 \\
\hline $\mathrm{ADF}$ & 56.78 & 56.04 & 61.79 & 1.14 & 0.0508 \\
\hline $\mathrm{NDF}$ & 60.71 & 58.71 & 63.85 & 1.02 & 0.0999 \\
\hline \multicolumn{6}{|c|}{ Nitrogen balance (g/d) } \\
\hline Intake N & $196.38^{b}$ & $203.8^{\mathrm{b}}$ & $217.3^{\mathrm{a}}$ & 3.35 & 0.0044 \\
\hline Fecal N & $57.67^{\mathrm{c}}$ & $63.91^{\mathrm{b}}$ & $68.09^{\mathrm{a}}$ & 1.58 & 0.0005 \\
\hline Urinary $\mathrm{N}$ & 52.49 & 52.08 & 50.16 & 1.97 & 0.9035 \\
\hline Retention N (\%) & 43.83 & 43.09 & 45.58 & 1.15 & 0.7201 \\
\hline
\end{tabular}


Table 6. Rumen $\mathrm{pH}$ and concentrations of VFA $(\mathrm{mmol} / \mathrm{L})$ and $\mathrm{NH} 3-\mathrm{N}(\mathrm{mg} / 100 \mathrm{ml})$ in steers fed different diets

\begin{tabular}{lccccc}
\hline \multirow{2}{*}{ Item } & \multicolumn{3}{c}{ Treatments } & \multirow{2}{*}{ SEM } & p value \\
\cline { 2 - 4 } & Control & $\mathrm{T}-1$ & 6.32 & 0.07 & 0.5638 \\
pH & 6.15 & 6.35 & 81.65 & 4.86 & 0.4078 \\
Total VFA & 97.36 & 83.62 & 58.45 & 3.43 & 0.5021 \\
Acetic acid (A) & 68.31 & 59.65 & 11.08 & 0.64 & 0.2253 \\
Propionic acid (P) & 13.20 & 10.57 & 8.63 & 0.78 & 0.2509 \\
Butyric acid & 11.89 & 9.90 & 1.20 & 0.06 & 0.6209 \\
Valeric acid & 1.05 & 1.06 & 5.73 & 0.16 & 0.4624 \\
A:P & 5.64 & 6.14 & 7.38 & 0.49 & 0.4736 \\
Ammonia-N & 8.61 & 7.10 & & &
\end{tabular}

from PD excretion was also not significantly different among the three kinds of synchronous treatments $(p>0.05)$.

\section{DISCUSSION}

The crude protein content in RWR was very similar to that of brewers dried grains (BDG) as reported by the National Research Council (2001) (28.67\% vs 29.2\%). RWR is composed primarily of the extracted residues of rice during rice wine production and is a high protein and energy source. According to Table 2, it was expected that RWR would be a high protein source as well as be a high energy source. In comparison to the $a$ fraction of crude protein in BDG (16.7\%) (Batajoo and Shaver, 1997), the value in RWR (11.72\%) is lower; however, the $b$ fraction of crude protein $(88.28 \%)$ in the RWR was higher than that in BDG as reported by Batajoo and Shaver (1997) (64.3\%) and that $(67 \%)$ reported by Pereira et al. (1998). In addition, the degradation rate $\left(\mathrm{k}_{\mathrm{d}}\right)$ of $\mathrm{N}$ in BDG $(0.072 / \mathrm{h})$ was faster than that of RWR $(0.02 / \mathrm{h})$. Differences observed in these fractions between RWR and BDG could be due to the variation in type of raw material or processing method. It is well known that the type of protein in corn is resistant to microbial digestion, and the degradability of starch is slow because of the association of the protein matrix with starch granules and the type and proportion of protein bodies found in the corn endosperm (McAllister et al., 1993). As expected, the degradation rates of $\mathrm{N}\left(\mathrm{k}_{\mathrm{d}}=0.02 / \mathrm{h}\right)$ and $\mathrm{CHO}$ $\left(\mathrm{k}_{\mathrm{d}}=0.03 / \mathrm{h}\right)$ in corn were lower than other feeds tested in this study. Protein fraction $a$ in the wheat bran was similar to that of the reported value of Melaku et al. (2003)
$(22.12 \%$ vs $21.95 \%)$; however, fraction $b$ in the present study was lower than the value of Melaku et al. (2003), and the degradation rate $\left(\mathrm{k}_{\mathrm{d}}\right)$ of $\mathrm{N}$ was also lower $(0.1 / \mathrm{h}$ vs $0.25 / \mathrm{h}$ ). Differences observed in these fractions between the same kinds of materials could be due to the variation in maturity of feedstuff, measurement method or the factors specific to the in situ experiment process. A substantial number of factors that have been evaluated from a number of studies including nylon bag and sample sizes, bag material and pore size, sample processing, animal diet, feeding level and frequency, bag insertion and removal procedure, location of bags within the rumen and containment procedures for the bags, incubation times, microbial correction, rinsing procedures, mathematical models, days, numbers of replicate animals and bags required to obtain repeatable estimates of ruminal degradation (Vanzant et al., 1998).

In this study, experimental diets were formulated to have similar nutrient content but different SI. All animals were fed the same amounts at the same time in order to avoid the influence of ingredient characteristics (Dewhurst et al., 2000) or intake level (Witt et al., 1999) on the effects of synchronization. Although the SI was altered, the apparent total tract digestibility values of DM, OM, NDF, $\mathrm{ADF}$ and $\mathrm{CP}$ were not significantly influenced, nor were rumen fermentation characteristics or MPS. The DM and OM digestibility of TMRs with higher SIs (MS and HS) were numerically higher than those of the control group (LS) but not significantly different. Although similar results have been reported in other studies (Chanjula et al., 2004; Rotger et al., 2006), it is not clear why SI did not affect total

Table 7. Purine derivative (PD) excretions in urine and microbial protein synthesis in steers fed experimental diets

\begin{tabular}{|c|c|c|c|c|c|}
\hline \multirow{2}{*}{ Item } & \multicolumn{3}{|c|}{ Treatments } & \multirow{2}{*}{ SEM } & \multirow{2}{*}{$\mathrm{p}$ value } \\
\hline & Control & $\mathrm{T}-1$ & $\mathrm{~T}-2$ & & \\
\hline \multicolumn{6}{|l|}{ Urinary PD (g/d) } \\
\hline Total & 30.37 & 34.47 & 33.25 & 1.95 & 0.7353 \\
\hline Allantoin & 17.37 & 19.57 & 19.02 & 1.09 & 0.7483 \\
\hline Uric acid & 13.00 & 14.91 & 14.23 & 1.10 & 0.8195 \\
\hline Microbial N (g/d) & 131.26 & 153.09 & 146.57 & 10.59 & 0.7457 \\
\hline
\end{tabular}


tract nutrient digestion. The impact of dietary SI in the lower digestive tract may have diluted the influence on rumen fermentation, although there was some indication that SI affected ruminal fermentation to some extent, as shown in differences in ammonia-N release. Kolver et al. (1998) reported that the apparent total tract digestibility values of $\mathrm{DM}, \mathrm{OM}$ and $\mathrm{CP}$ were not improved by supplementation of carbohydrate-rich feed with pasture $\mathrm{N}$ in the rumen.

The ruminal $\mathrm{pH}$, VFA and ammonia-N of steers fed three different diets were not significantly different. Even though the ruminal ammonia- $\mathrm{N}$ concentration of the control group at $3 \mathrm{~h}$ after feeding (figure not shown) was the highest among the three groups, this may be the result of inclusion of urea in the control diet. Ruminal ammonia- $\mathrm{N}$ is known to be mostly transferred into the liver and converted into urea, with a portion of it being used for MPS. A high ammonia- $\mathrm{N}$ content indicates less efficient utilization of $\mathrm{N}$ for MPS. Thus, since the carbohydrate contents of the three diets were similar in this study, neither the lack of carbohydrate in the control diet nor inefficient degradation of other protein components were responsible for the higher ammonia concentration of the control group. We postulated that the HS group may have produced more volatile fatty acid because, according to the synchronization theory, the high SI diet fed to cattle can produce more MCP, and the increasing number of microbes can utilize the diet more efficiently to produce much more VFA. In the present study, the digestibility values of DM, OM and CP or microbial-N (MN) among the three groups were not significantly different, which indirectly indicates that the VFA concentrations of the three groups were not significantly different. A number of studies (Shabi et al., 1998; Witt et al., 1999; Kaswari et al., 2007) showed similar results that ruminal $\mathrm{pH}, \mathrm{NH}_{3}-\mathrm{N}$ and total VFA were not influenced by SI. In addition, in this study, the PD excretion and the MN calculated by the amount of PD excretion in the urine were not significantly different among the three groups; however, the MN content of each group was greater than those in other studies (Valkeners et al., 2004; Chumpawadee et al., 2006). Henning et al. (1991) and Kim et al. (1999) also reported that both synchronization and asynchronization conditions showed no effect on MPS.

Theoretically, synchronous nutrient availability should lead to more efficient use of nutrients, thus improving production of microbial products, nutrient supply to the animal, and potentially animal production performance (Hall and Huntington, 2008). However, studies have frequently failed to show improved $\mathrm{MN}$ and animal performance. Hall and Huntington (2008) suggested that other factors in addition to the rumen and the feed should be considered, and future study needs to consider the larger picture and complexity of the interaction of the animal, its environment, the ruminal microbes, and the diet. Moreover, the ingredients, rates of nitrogen and carbohydrate degradation, particularities of the in situ procedure, and better understanding of the complex ruminal ecosystem and physiological effects are required.

\section{ACKNOWLEDGEMENTS}

This study was carried out with the support of the Cooperative Research Program for Agricultural Science \& Technology Development (Project No. 20090101-030-166001-03-00), Rural Development Administration, Republic of Korea.

\section{REFERENCES}

AOAC. 1990. Official methods of analysis. $15^{\text {th }}$ Edn. Association of Official Analytical Chemists, Arlington, Virginia, USA.

Batajoo, K. K. and R. D. Shaver. 1998. In situ dry matter, crude protein, and starch degradabilities of selected grains and byproduct feeds. Anim. Feed.Sci. Technol. 71:165-176.

Beever, D. E. and R. C. Siddons. 1986. Digestion and metabolism in the grazing ruminant. In: Control of digestion and metabolism in ruminants (Ed. L. P. Milligan, W. L. Grovum and A. Dobson). pp. 479-497. Prentice-Hall, Englewood Cliffs, NJ, USA.

Chanjula, P., M. Wanapat, C. Wachirapaorn and P. Rowlinson. 2004. Effects of synchronizing starch sources and protein (NPN) in the rumen of feed intake, rumen microbial fermentation, nutrient utilization and performance of lactating dairy cows. Asian-Aust. J. Anim. Sci. 17:1400-1410.

Chen, X. B., D. B. F. D. Hovell, E. R. Orskov and D. S. Brown. 1990. Excretion of purine derivatives by ruminants: Effect of exogenous nucleic acid supply on purine derivative excretion by sheep. Br. J. Nutr. 63:131-142.

Chen, X. B., Y. K. Chen, M. F. Franklin, E. R. Orskov and W. J. Shand. 1992. The effect of feed intake and body weight on purine derivative excretion and microbial protein supply in sheep. J. Anim. Sci. 70:1534-1542.

Chumpawadee, S., K. Sommart, T. Vongpralub and V. Pattarajinda. 2006. Effects of synchronizing the rate of dietary energy and nitrogen release on ruminal fermentation, microbial protein synthesis, blood urea nitrogen and nutrient digestibility in beef cattle. Asian-Aust. J. Anim. Sci. 19:181-188.

Clark, J. H., T. K. Klusmeyer and M. R. Cameron. 1992. Microbial protein synthesis and flows of nitrogen fractions to the duodenum of dairy cows. J. Dairy Sci. 75:2304-2323.

Dewhurst, R. J., D. R. Davies and R. J. Merry. 2000. Microbial protein supply from the rumen. Anim. Feed Sci. Technol. 85: $1-21$.

George, S. K., M. T. Dipu, U. R. Mehra, P. Singh, A. K. Verma and J. S. Ramgaokar. 2006. Improved HPLC method for the simultaneous determination of allantoin, uric acid and creatinine in cattle urine. J. Chromatogr. B 832:134-137.

Hall, M. B. and G. B. Huntington. 2008. Nutrient synchrony: sound in theory, elusive in practice. J. Anim. Sci. 86:E287E292. 
Henning, P. H., D. G. Steyn and H. H. Meissner. 1991. The effect of energy and nitrogen supply pattern on rumen bacteria growth in vitro. Anim. Prod. 53:165-175.

Henning, P. H., D. G. Steyn and H. H. Meissner. 1993. Effect of synchronization of energy and nitrogen supply on ruminal characteristics and microbial growth. J. Anim. Sci. 71:25162528.

Herrera-Saldana, R., R. Gomez-Alarcon, M. Torabi and J. T. Huber. 1990. Influence of synchronizing protein and starch degradation in the rumen on nutrient utilization and microbial protein synthesis. J. Dairy Sci. 73:142-148.

Hoover, W. H. and S. R. Stokes. 1991. Balancing carbohydrate and protein for optimum rumen microbial yield. J. Dairy Sci. 74:3630-3644.

Johnson, R. R. 1976. Influence of carbohydrate solubility on nonprotein nitrogen utilization in the ruminant. J. Anim. Sci. 43:184-191.

Kim, K. H., Y. G. Oh, J. J. Choung and D. G. Chamberlain. 1999. Effects of varying degrees of synchrony of energy and nitrogen release in the rumen on the synthesis of microbial protein in cattle consuming grass silage. J. Sci. Food Agric. 79:833-838.

Kolver, E., L. D. Muller, G. A. Varga and T. J. Cassidy. 1998. Synchronization of ruminal degradation of supplemental carbohydrate with pasture nitrogen in lactating dairy cows. J. Dairy Sci. 81:2017-2028.

McAllister, T. A., R. C. Phillippe, L. M. Rode and K. J. Cheng. 1993. Effect of the protein matrix on the digestion of cereal grains by ruminal microorganisms. J. Anim. Sci. 71:205-212.

Melaku S., K. J. Peters and A. Tegegne. 2003. In vitro and in situ evaluation of selected multipurpose trees, wheat bran and Lablab purpureus as potential feed supplements to tef (Eragrostis tef) straw. Anim. Feed Sci. Technol. 108:159-179.

Owens, F. N. and W. G. Bergen. 1983. Nitrogen metabolism of ruminant animals: Historical perspective, current understanding and future implications. J. Anim. Sci. 57:498518.

Peter Wen-Shyg Chiou, Chao-Ren Chen, Kuen-Jaw Chen and Bi Yu. 1998. Wet brewers' grains or bean curd pomace as partial replacement of soybean meal for lactating cows. Anim. Feed Sci. Technol. 74:123-134

Pereira, J. C., M. D. Carro, J. Gonzalez, M. R. Alvir and C. A. Rodriguez. 1998. Rumen degradability and intestinal digestibility of brewer's grains as affected by origin and heat treatment and of barley rootlets. Anim. Feed Sci. Technol. 74:107-121.

Richardson, J. M., R. G. Wilkison and L. A. Sinclair. 2003. Synchrony of nutrient supply to the rumen and dietary energy source and their effects on the growth and metabolism of lambs. J. Anim. Sci. 81:1332-1347.

Rotger, A., A. Ferret, S. Calsamiglia and X. Manteca. 2006. Effects of nonstructural carbohydrate and protein sources on intake, apparent total tract digestibility, and ruminal metabolism in vivo and in vitro with high-concentrate beef cattle diets. J. Anim. Sci. 84:1188-1196.
SAS. 2002. SAS user's guide: Statistics (Version 9.01 Ed). SAS Inst. Inc., Cary, NC, USA.

Shabi, Z., A. Arieli, I. Bruckental, Y. Aharoni, S. Zamwel, A. Bor and H. Tagari. 1998. Effect of the synchronization of the degradation of dietary crude protein and organic matter and feeding frequency on ruminal fermentation and flow of digesta in the abomasums of dairy cows. J. Dairy Sci. 81:1991-2000.

Sinclair, L. A., P. C. Garnsworthy, P. Beardsworth, P. Freeman and P. J. Buttery. 1991. The use of cytosine as a marker to estimate microbial protein synthesis in the rumen. Anim. Prod. 52:592(Abstr).

Sinclair, L. A., P. C. Garnsworthy, J. R. Newbold and P. J. Buttery. 1993. Effect of synchronizing the rate of dietary energy and nitrogen release on rumen fermentation and microbial protein synthesis in the sheep. J. Agric. Sci. 120:251-263.

Snedecor, G. W. and W. G. Cochran. 1967. Statistical methods $\left(6^{\text {th }}\right.$ Ed.). Iowa State Univ. Press, Ames.

Teja Kaswari, Peter Lebzien, Gerhard Flachowsky and Udo ter Meulen. 2007. Studies on the relationship between the synchronization index and the microbial protein synthesis in the rumen of dairy cows. Anim. Feed Sci. Technol. 139:1-22.

Valkeners, D., A. Tahewis, F. Piron and Y. Beekers. 2004. Effect of imbalance between energy and nitrogen supplies on microbial protein synthesis and nitrogen metabolism in growing double muscled Belgian Blue bulls. J. Anim. Sci. 82:1818-1825.

Van Soest, P. J., J. B. Robertson and B. A. Lewis. 1991. Methods for dietary fiber, neutral detergent fiber, and non-starch polysaccharides in relation to animal nutrition. J. Dairy Sci. 74:3583.

Van Vuuren, A. M., S. Tamminga and R. S. Ketelaar. 1991. In sacco degradation of organic matter and crude protein of fresh grass (Lolium perenne) in the rumen of grazing dairy cows. J. Agric. Sci. (Camb) 116:429-436.

Vanzant, E. S., R. C. Cochran and E. C. Titgemeyer. 1998. Standardization of in situ techniques for ruminant feedstuff evaluation. J. Anim. Sci. 76:2717-2729.

Witt, M. W., L. A. Sinclair, R. G. Wilkinson and P. J. Buttery. 1999. The effects of synchronizing the rate of dietary energy and nitrogen supply to the rumen on the metabolism and growth of ram lambs given food at a restricted level. J. Anim. Sci. 69: 627-636.

Witt, M. W., L. A. Sinclair, R. C. Wilkinson and P. J. Buttery. 1999 The effects of synchronizing the rate of dietary energy and nitrogen supply to the rumen on the production and metabolism of sheep: food characterization and growth and metabolism of ewe lambs given food ad libitum. J. Anim. Sci. 69:223-235.

Xu, C., Y. Cai, N. Moriya and M. Ogawa. 2007. Nutritive value for ruminants of green tea grounds as a replacement of brewers' grains in totally mixed ration silage. Anim. Feed Sci. Technol. 138:228-238.

Yang, J. Y., J. Seo, H. J. Kim, S. Seo and J. K. Ha. 2010. Nutrient synchrony: Is it a suitable strategy to improve nitrogen utilization and animal performance? Asian-Aust. J. Anim. Sci. 23:972-979. 